Rowena A. Pecchenino is a professor of economics at Michigan State University. Patricia S. Pollard is a senior economist at the Federal Reserve Bank of St. Louis. Heidi L. Beyer provided research assistance.

\section{Reforming Social Security: A Welfare Analysis}

\author{
Rowena A. Pecchenino and \\ Patricia S. Pollard
}

 he U.S. Social Security System was conceived as a means to ensure a minimum standard of living for the elderly, and it has done so. Poverty rates among the old have dropped, and many retirees can now look forward to a comfortable retirement, funded in part by their Social Security benefits. However, the system's ability to provide future retirees with a comparable retirement income has been called into question, and plans that would fundamentally change the system have been proposed.

When the Social Security System was established in 1935, it envisioned the creation of a large reserve fund to ensure the continued financing of the system. Benefits were not scheduled to be paid to those reaching the age of 65 until 1942 and were to be based on total lifetime earnings of contributors. Before the first dollar was paid out, the system was amended in 1939. Benefits were to begin in 1940 and would be based on average earnings over a minimum covered period, thereby raising the ben efits received by the average worker. In addition, coverage for a retiree's dependent children and spouse were added. These changes resulted in an increase in initial payments made by the system and eliminated the idea of building up a reserve fund. Social Security became grounded as a pay-as-you-go system - contributions made by current workers would be transferred in the form of benefits to current retirees. Current workers then would rely upon their children's generation to finance their retirement benefits.

When Social Security was established, it covered only workers engaged in commerce and industry (excluding rail lroad workers), about 60 percent of the workforce. Over the years, most notably in the 1950s and 1960s, coverage was expanded so that today 96 percent of all jobs are covered by Social Security. There are five categories of excluded workers: 1) federal civilian employees hired prior to 1994; 2) railroad workers (although the railroad retirement program is coordinated with Social Security); 3) state and local employees, if they are covered under a separate retirement program (currently 25 percent of state and local workers are excluded); 4) household and farm workers whose earnings are below some minimum requirement; and 5) self-employed workers with earnings below $\$ 400$ a year. ${ }^{1}$

Over the years, the types of benefits have expanded, particularly relating to dependent coverage and survivors. Disability coverage was added, and early retirement programs were instituted. In addition, the benefit formulas were changed, resulting in increases in benefits for all retirees. Thus, while the average single worker who retired at age 65 in 1940 received benefit payments in that year equal to 26 percent of his pre-retirement wage, the average single worker who retired at age 65 in 1997 received benefits payments in that year equal to 45 percent of his pre-retirement wage.2

Not only have the benefits received by retirees been rising, but the number of years a retiree is likely to receive benefits has risen due to increases in life expectancy. A person retiring in 1940 was expected to receive benefits for 12 years, if a man, and 13 years, if a woman. In contrast, a person retiring in 1997 is expected to receive benefits for 16 years, if a man, and 19 years, if a woman. The increasing generosity of the Social Security system and the increase in life expectancy have added to the cost of financing the system.

\footnotetext{
1 Social Secunity Administration (1997).

2 U.S. Congress (1996) and Social Security Administration (1997).
} 
${ }^{3}$ Of this 12.4 percent, 10.7 is for the Old-Age and Survivors portion of Social Security, and the other 1.7 percent is for the Disability portion. The latter aspect of Social Security did not exist in 1935.

4 Beginning in 1983, the United States undertook a program to accumulate a large trust fund by raising taxes well above the prevaling financing needs of the system. The money in this trust fund is invested in government securities.

${ }^{5}$ Board of Trustees of the Federal Old-Age Disability and Survivors Trust Fund (1996).

6 In 1965, the U.S. Social Security Act was amended to require that an advisory council be established every four years to analyze the long-term health of the Social Security program. Legislation passed after the establishment of the 1994-96 Advisory Council eliminated this requirement.

${ }^{7}$ An annuity provides a constant stream of payments throughout the retirement, regardless of the life span of an individual. An annuity is actuarially fair if its expected value is equal to the real retum on non-annuitized saving.

8 Note that the expected value of the annuity,

$p\left(\frac{1+r}{p}\right)$ does equal the return on non-annuitized saving, $1+r$.
W hile benefits have risen, so too have the tax rates necessary to fund these benefits. Social Security tax rates are split equally between employer and employee. In 1935, the combined tax rate was 1 percent of wages. Today the combined tax rate is 12.4 percent. $^{3}$ Demographic and economic changes have raised concerns about the ability of the system to maintain the current levels of generosity without further increases in taxes. With declining fertility rates, the potential growth of the labor force is declining. Furthermore, declines in the rate of productivity growth since the 1970s have reduced the growth in real wages and thus payments.

According to the 1996 report of the Social Security Board of Trustees, payments made by the Social Security Administration will exceed contributions beginning in 2013. The deficit will be financed through the trust fund. ${ }^{4}$ By 2029 the trust fund will be exhausted. In the following year, contributions will cover only 75 percent of payments. ${ }^{5}$

In 1994, Congress appointed an Advisory Council to study the problems facing Social Security and to devise a plan to address these problems. ${ }^{6}$ The Advisory Council could not agree on a single plan, but instead suggested three competing plans. This paper develops a model to analyze these reform proposals.

The next section provides a simple example to illustrate the problems facing a pay-as-you-go social security system. N ext, the paper provides a brief analysis of the proposals of the Advisory Council. The remainder of the paper analyzes the effects of these reforms on economic growth and individuals' welfare.

\section{A SIMPLE MODEL OF A PAY-AS-YOU-GO SYSTEM}

Before the new plans can be considered, the current pay-as-you-go system and its perceived failings must be well understood. To see how a basic pay-as-you-go social security system works, we will consider a very simple economy. The population of the economy is divided into two groups- workers and retirees. Assume that there are al ways $(1+n)$ workers per $p$ retirees; thus the ratio of retirees to workers, the aged-dependency ratio, is $p /(1+n)$. Assume also that each successive generation of workers earns real wages $\omega$ percent higher than its predecessor, so that wages are growing at rate $\omega$. The government assesses a payroll $\operatorname{tax}, \tau$, on the wages of the workers to fund the social security benefits of the retirees.

Consider two successive generations of retirees. If the initial wage is $w$, the first generation will receive benefits of $\tau w(1+n) / p$ per person, and the second generation will receive $\tau w(1+n)(1+\omega) / p$ per person. Higher real wage (productivity) growth, $\omega$, and/or a higher tax rate, $\tau$, will raise benefits for the second generation. In contrast, a higher ageddependency ratio, $p /(1+n)$, will lower benefits for the second generation. These relationships are true for any pair of generations.

Is the return on this system good for the individual saver? Suppose that, in the absence of a social security system, an individual saves during his working years $\tau$ w (the amount he would have contributed to the system), and assume that actuarially fair annuity contracts are not available. ${ }^{7}$ Then the real return to the worker's savings is $(1+r)$, and the worker will have $(1+r) \tau w$ to fund his retirement. If

$$
(1+r)>\left(\frac{1+n}{p}\right)(1+\omega),
$$

then the worker will have a higher income in retirement from personal savings than he would have had under the social security system. If, however, the inequality given by (1) is reversed, then the worker would have been better off to have saved for retirement through a social security system.

Now suppose that actuarially fair annuity contracts are available and a worker places all of her savings in an annuity. The real return to her savings in this case is $(1+r) / p$ (when all savers annuitize their saving), 8 and the worker will have $(1+r) \tau \mathrm{w} / \mathrm{p}$ to fund her retirement. If 


$$
\text { (2) } \frac{1+r}{p}>\left(\frac{1+n}{p}\right)(1+\omega) \text {, }
$$

the worker will have a higher income in retirement from personal savings than she would have had under the social security system. If, however, the inequality given by (2) is reversed, then the worker would have been better off if a social security system had been in place.

The results of these simple examples can be summarized as follows: A pay-asyou-go social security system benefits the current generation and all future generations if the productivity growth rate, $\omega$, is high enough and the aged-dependency ratio is low enough. The availability of actuarially fair annuity contracts makes the return to private savings higher and thus makes the viability of the pay-as-you-go system proportionately more sensitive to changes in demographics and productivity.

Although the productivity growth rate has been high enough and the ageddependency ratio low enough in the past to make our present social security system a success, current trends do not bode well for its future. The last decades of the twentieth century have seen a marked decline in the birth rate and a significant increase in longevity in the United States. Together, these trends have resulted in a higher percentage of elderly persons in the population (see Figure 1), an outcome that can be represented in our simple model by an increase in $p /(1+n)$. During this same period, the rate of productivity growth has also declined (see Table 1) - a phenomenon that can be expressed in our model by a reduction in $\omega$. Both trends suggest that if the current tax rate is kept constant, benefits will decrease. If benefits are to remain constant, the tax rate must be increased. N either choice is without cost.

\section{Reforming Social Security}

In response to these demographic and productivity trends, a recent report by the government's 1994-96 Advisory Council on Social Security has suggested three

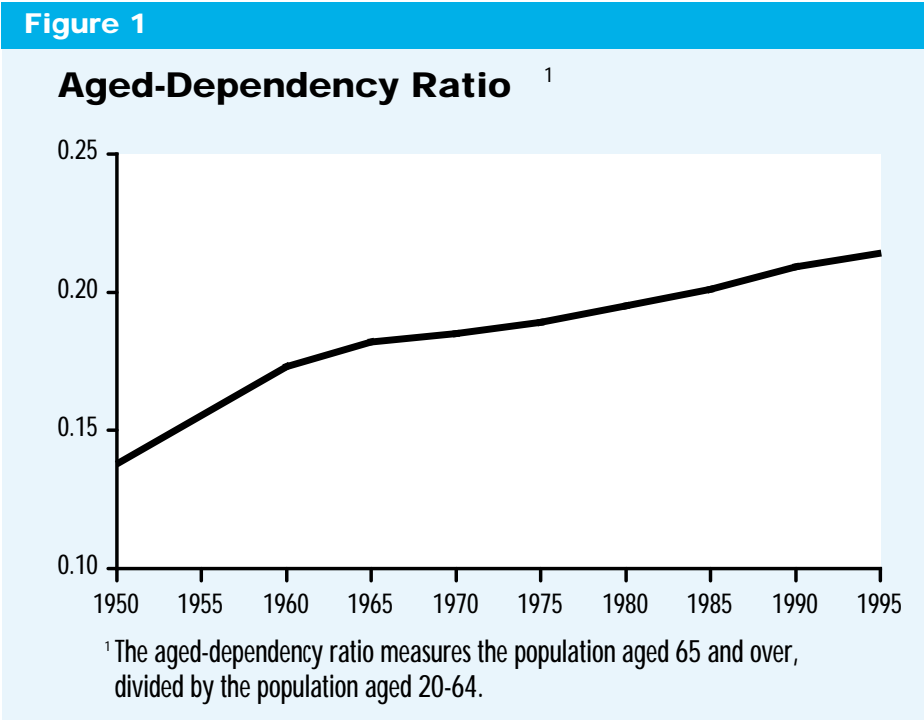

\section{Table 1}

Labor Productivity

Average Annual Growth in Business Sector Output per Hour

\begin{tabular}{|c|l|}
\hline $1950-59$ & $2.88 \%$ \\
\hline $1960-69$ & 3.36 \\
\hline $1970-79$ & 2.03 \\
\hline $1980-89$ & 1.40 \\
\hline $1990-96$ & 0.95 \\
\hline $1950-72$ & 3.07 \\
\hline $1973-96$ & 1.14 \\
\hline
\end{tabular}

plans to modify the U.S. Social Security System: a maintain benefits (MB) plan, an individual accounts (IA) plan, and a personal security accounts (PSA) plan. All three plans would increase the number of workers who contribute to the system by extending coverage to all new state and local employees. At the same time, benefits to current and future retirees would be reduced slightly under all the plans through a tax on all Social Security benefits in excess of previously taxed employee contributions. ${ }^{9}$

The goal of the MB plan is to minimize changes to the structure of the current system while ensuring its financial stability. Benefits would be reduced slightly in

\footnotetext{
9 This change would provide comparable treatment of Social Security benefits and other pension benefits.
} 
conjunction with future increases in

payroll tax rates.

Both the IA plan and the PSA plan would accelerate scheduled increases in the retirement age while indexing future retirement-age increases to increases in longevity. The key element of the former plan is a proposed 1.6 percent increase in the Social Security payroll taxes on employees. This portion of the tax revenues would be placed in governmentmanaged, individually owned asset portfolios. Upon the employee's retirement, these funds would be converted into annuities that would be indexed to provide protection against inflation.

Under the IA plan, the bulk of the Social Security program would continue to be maintained as a pay-as-you-go system, with revenues from the 12.4 percent Social Security tax being transferred from workers to retirees, as at present. To make the system financially sound, the growth of basic benefits would be reduced, particularly for those retirees who were middle and high-wage workers. In addition, dependent-spouse benefits would be reduced.

The PSA plan would move the system closest to a fully funded program, with 5 percent of the current Social Security payroll tax allocated to personal retirement accounts held and managed by private investment firms. Individuals would have a wider range of investment opportunities than under the IA plan, and they would not be required to convert their funds to annuities upon retirement. Workers 55 and older would continue to be covered under the existing system. Workers between the ages of 25 and 54 would receive retirement benefits based on benefits accrued under the old system as well as contributions to the new system. Those under the age of 25 would be covered solely by the new system. A temporary payroll tax increase would be used to finance this transition period. The remaining 7.4 percent payroll tax would be used to provide a minimum level of income for all retirees. ${ }^{10}$

According to analyses conducted by the Social Security Office of the Chief Actuary, all three plans would keep the system in actuarial balance for the next 75 years. However, these analyses did not take into account the effects that endogenous changes in individuals' savings decisions could have on capital accumulation, interest rates, and wages.

To examine these endogenous responses and analyze simplified versions of the Advisory Council's plans, we first developed a model of an economy with an extant payas-you-go social security system. In this economy, individuals work when young and allocate their income to current consumption, saving for future consumption, and payment of social security taxes. When old, individuals retire and consume their accumulated savings and social security benefits. Their consumption/saving decisions determine the level and growth rate of the capital stock and thus the interest rate, the wage rate, and the productivity growth rate. Since they cannot predict with any accuracy when they will die, they may have leftover savings to bequeath to their children. Without modification, this model allows us to examine the M B plan. We extend it to examine the IA and PSA plans by allowing for government investment on individuals' accounts and for individual investment in retirement accounts mandated by the government but controlled by the workers. In our model, as in the IA plan, all government investment will be converted to annuities upon the retirement of the account holders. Further, annuities also will be available to individual employees under the PSA version of the model; however, the employee will not be required to invest in them, and their availability may be rationed.

\section{THE MODEL}

In this section we briefly discuss the assumptions underlying the model. ${ }^{11}$ We consider an infinite-horizon economy comprised of identical individuals, perfectly competitive firms, annuity markets, and a government.

\section{Characteristics of Individuals}

A new generation is born at each date, $t$. For simplicity we assume that there is no population growth. This assumption 
enables us to concentrate attention on the aged-dependency ratio rather than on fertility trends. Individuals in this model, as in Eckstein, et al. (1985), are not altruistic. Individual preferences are defined on the basis of consumption alone. In the first period of life, each young individual is endowed with one unit of labor, which he or she supplies inelastically to firms. Wages and bequests, if any, are allocated among the worker's current consumption, savings for consumption in retirement (in the form of an annuity, direct holdings of capital, or both), and payment of social security taxes, $\tau$, quoted as a proportion of the worker's wages. In the final period of their lives, individuals retire and supply their savings inelastically to firms and consume their after-tax social security benefits and their accumulated savings. Individual life spans are uncertain. The probability that an individual will die at the onset of retirement is [1-p(t)] and the probability that he will live throughout the retirement period is $p(t)$. If an individual dies at the onset of retirement, his unannuitized wealth is bequeathed to his children.

In this model, a person wishes to allocate his wage and bequest incomes over the course of his lifetime to maximize his consumption. Many factors affect this allocation decision.

First, the longer he expects to live, the greater the necessity of saving. But he cannot predict how long he will live.

Second, how much he needs to save will depend on the return to his private savings. But higher returns to private savings induce two contrary effects. They mean that future consumption is cheap relative to current consumption, so deferring consumption makes sense. However, they also mean he can save less without reducing future consumption. So the worker must choose between deferred gratification and increased current consumption. In addition, the return to private savings can be affected by the availability of actuarially fair annuity contracts. All el se equal, the return on a portfolio increases with the percentage held as an annuity.
Finally, anticipated social security benefits can affect the decision to save. The more one expects to receive, the less need there is for one to save. However, benefits must be paid for, and higher benefits require higher taxes. As a result, there will be less after-tax income to spend or save.

The individual worker must balance all these forces to decide upon a lifetime consumption path.

\section{The Role of Firms}

The firms in our model are perfectly competitive profit maximizers that produce output using a Cobb-Douglas production function $Y(t)=A(t) K(t)^{\beta} N(t)^{1-\beta}, \beta \in[0,1]$. $\mathrm{K}(\mathrm{t})$ is the capital stock at $\mathrm{t}, \mathrm{N}(\mathrm{t})$ is employment at $\mathrm{t}$, and $\mathrm{A}(\mathrm{t})>0$ is a productivity scalar. Capital depreciates fully in the production process. ${ }^{12}$ The production function can be written in intensive form as $y(t)=A(t) k(t)^{\beta}$, where $k(t)$ is the capitallabor ratio. Assume, because of external effects of aggregate capital on productivity, as suggested by Romer (1986), $A(t)=$ $\mathrm{a}(\mathrm{t}) \mathrm{K}(\mathrm{t})^{\eta}, \mathrm{a}(\mathrm{t})>0, \eta \geq 0$, so that the aggregate capital stock, $K(t)$, enters the technology as a constant from the perspective of current producers. This formulation allows a straightforward analysis of the effects of personal actions - and those of the government- on economic growth. It is not necessary for our major conclusions.

\section{Government's Role}

The government in our model economy can impose social security taxes, $\tau(t)$, on the wages of the young at time $t$. It may also impose a tax on the social security benefits of the retired if retirees' income exceeds some means test. Finally, it may adjust a retiree's social security benefit to guarantee that his/her total income (saving and social security benefits) is at least some fraction, $\zeta$, of per capita gross domestic product, $y(t)$. With a means test, if a retiree's total income is more than some multiple $(1+\xi)$ of the guaranteed income, $\zeta y(t)$, then her social security benefits are taxed at the rate $\sigma$. The

\footnotetext{
${ }^{12}$ Given that we will treat each time period, $t$, as 25 years, this is not an extreme assumption.
} 
government must fully fund all expenditures with tax receipts; it must have a balanced budget.

\section{Annuity Market}

We assume initially, following Sheshinski and Weiss (1981), that actuarially fair annuity contracts are unavailable on the private market. The government overcomes this market failure by establishing a market in actuarially fair annuity contracts, and once the market is established, it has an interest in controlling access to this market (see the following section). There are several ways that the government could control access. First, it could place restrictions on annuity purchases, similar to the restrictions it currently places on tax-deferred investments. In this case, individuals could annuitize some percentage of their total savings upon retirement. Second, the government could mandate that each individual place a fixed amount in an annuity. Third, it could license private firms to provide actuarially fair annuities as part of a mutual fund but restrict the proportion of the fund that could be annuitized. The first and third methods of accessing the annuity market are identical in the context of our model. The second method is what is imagined for the implementation of the IA plan.

\footnotetext{
${ }^{13}$ This is essentially the assumption made by the Office of the Chief Actuary when examining the Advisory Council's plans.
}

\section{THE CASE AGAINST FULL ANNUITIZATION}

The current pay-as-you-go social security system provides retirees with an annuity, disbursing benefits throughout their retirement regardless of how long they live. However, the link between one's contributions and one's benefits is broken by the pay-as-you-go structure of the program. In contrast, private pension plans often allow or require annuitization of pension benefits. These plans are increasingly defined-contribution plans that, although they pay out for as long as a retiree lives, directly link pension bene- fits to the amount contributed and market returns on the asset portfolio in which the contributions were invested. Thus, annuity contracts are al ready a large part of retirees' investment portfolios. We are interested in determining the effects of annuitizing saving in order to determine whether annuitization should be a part of a modified social security structure, as has been suggested by the IA plan.

Sheshinski and Weiss (1981) find in a simple model in which the interest rate is exogenously fixed that the socially optimal, fully funded social security scheme for individuals who have no bequest motive (as in our model), is one in which individual workers place all their savings in annuities. ${ }^{13}$ In the Sheshinski-Weiss model, individual optimality and social optimality coincide. In our model, savings decisions affect the capital stock and thereby the interest rate. Individual workers still want to invest in assets that offer the highest return possible, and in our case this is an annuity. (This model suggests that, while the PSA plan does not mandate annuitization of saving, actuarially fair contracts will be purchased if they are available.) But if individuals can fully annuitize their saving, they will not leave any unintentional bequests. Workers will see their disposable income reduced, and they will save less. Further, because they can hold an annuity, they will face less risk in not being able to predict when they will die. This also lowers saving. Since the rate of saving is closely linked to the rate of growth, the government will want to encourage saving and thus discourage (although not necessarily prohibit) the purchase of annuity contracts.

\section{COMPARATIVE DYNAMICS}

The partial equilibrium analyses of the social security plans suggested by the Advisory Council are silent on the effects of these new plans on individual savings choices, and thus on capital accumulation and growth. Our model is 
simple enough to allow us to examine these effects. In this section we assume that the conditions for growth are met (see Pecchenino and Pollard, N ovember 1997), and we summarize how economic growthand thus the actuarial balance of the plans-is affected by the following: changes in the social security tax rate, demographic changes that extend the period of retirement, changes in the percentage of savings held as an annuity, and the presence of a means test or income guarantee. These results will provide us with intuition that we will use to assess whether the Advisory Council's plans will be in actuarial balance once the general equilibrium effects have been taken into account. They will also help us to design an alternative plan under which actuarial balance is maintained in the face of the general equilibrium effects.

We find that, all else equal, pay-asyou-go social security taxes create strong disincentives to saving. Accordingly, increases in the tax rate, $\tau$, reduce growth. This phenomenon results because an increase in the social security tax rate imposes a negative income effect on workers and a positive income effect on retirees via higher social security benefits. Both effects reduce saving, which reduces capital accumulation and hence the growth rate of per capita income. This line of reasoning suggests that, all else equal, increasing the social security tax rate will undermine actuarial balance. Thus the planned increases in social security taxes that are designed to keep the $M$ aintained Benefits plan in balance may have an effect opposite to that intended.

Demographic considerations also affect saving behavior, and these effects interact with the features of the social security system and the methods of saving available. For example, if all weal th is annuitized, then the rate of economic growth increases with the expected length of life. This happens because greater longevity tends to heighten people's incentive to save, thereby increasing society's capital accumulation. If wealth is only partially annuitized, increased life span also reduces bequests, since people who live longer consume a greater proportion of their wealth. At the same time, the marginal return to an annuity, $(1+r) / p$, and social security benefits are decreased, since the tax revenues must be shared among a larger population of retirees. The first two effects reduce the incentive to save, while the last one increases it; the net effect is ambiguous. Thus it may be that leaving well enough alone is a feasible option (in the sense of actuarial balance) and the tax increases and benefit reductions mooted for the MB plan may not be necessary. Further, in light of increasing longevity, it may not be necessary to increase the age of eligibility for Social Security, as suggested under the PS and IA plans, since individuals will plan for their longer period of retirement by saving more.

W hile economic analysis suggests that savers would choose to fully annuitize their saving upon retirement, in actuality the percentage of savings now held in annuity contracts in the United States is relatively small, in large part because of market failures. ${ }^{14}$ If access to annuity markets were improved by the introduction of actuarial ly fair contracts, and if a greater percentage of weal th were annuitized, then bequests would fall, effectively reducing workers' income. The workers would then respond by reducing both their rate of saving and their consumption today. However, an increase in the percentage of annuitized wealth increases the return to saving, which has a positive income effect on the workers. In the absence of a pay-as-you-go social security scheme in which savings can be annuitized, only the negative bequest effect is realized, leading to reduced saving and reduced growth. With a pay-as-yougo scheme, the two effects interact. If the bequest effect is weaker than the annuitization effect, saving and growth will rise. If it is not, higher rates of annuitization may lead to decreased saving and lower rates of growth; actuarially fair annuities may decrease dynamic social welfare. Thus, the PSA and IA plans may not have their intended effects and could worsen rather than improve actuarial balance.

\footnotetext{
14 This calculation of annuitized saving does not include Social Security.
} 
Under the IA plan, it is possible that individuals will not choose to save beyond the government-mandated level. If this is the case, then increasing mandated saving is equivalent to increasing the percentage of savings held as annuities but with no negative side effects on bequests. Thus saving, and therefore capital accumulation and growth, will increase, ${ }^{15}$ and actuarial balance will be maintained or improved.

Because individuals are identical in our model, a means test will either reduce the benefits of all retirees or affect no one's benefits. Similarly, an income guarantee will either raise the benefits of all retirees or affect the benefits of no retiree. With a means test, if the income of each retiree exceeds the cutoff income level, $(1+\xi) \zeta y(t)$, then the retiree's social security benefits are taxed. This action effectively reduces retirees' incomes and increases workers' incentives to save. Thus capital accumulation and growth rise. An income guarantee has the opposite effect. Since no matter what consumption and saving choices individuals make when they are young, they will not be left destitute in retirement, they have less incentive to save. Further, the more generous the income guarantee, the higher will be the taxes imposed on workers to fund it. This step also reduces saving and thereby capital accumulation and growth. Thus, while means testing may improve actuarial balance, the imposition of a minimum income guarantee, all else equal, will not.

\section{DYNAMIC SOCIAL WELFARE}

Policies aimed at fundamentally changing the Social Security System must garner the necessary political support. To do so, they must benefit current constituents. Thus, any growth-inducing policy that enhances the actuarial balance of the Social Security program must do so without hurting either current beneficiaries or current workers. In this section we analyze policies that improve the well-being of current workers and beneficiaries as well as that of all future generations. These policies, while similar to the plans suggested by the Advisory Council on Social Security, avoid the general equilibrium pitfalls identified above.

We analyze the various policies by simulating three variations of our model. In each variant we assume that actuarially fair annuity contracts are available, although the percentage of an individual's weal th that can be annuitized may be restricted. In the first variation, the means test is binding, so the social security benefits of all retirees are taxed. In the second variation, the income guarantee is binding, so all social security recipients have incomes below the income guarantee threshold. In the third variation, neither the means test nor the income guarantee is binding, so all social security recipients have incomes above the minimum guarantee but below the tax-free ceiling. Another variation of the model, in which the government mandates saving, such as the IA plan, is not simulated. If the level of mandated saving is less than what individuals would voluntarily choose to save, then any increase in forced saving decreases growth and so cannot improve actuarial balance. On the other hand, if the level of mandated saving exceeds what individuals would voluntarily choose to save, then they are worse off as a result of the program, so while it may improve actuarial balance, it will lack political support.

To begin our analysis, we first create a set of baselines by calibrating the economy to achieve a 2 percent growth rate per year. The parameters for the economy used in the baseline simulation, given in Table 2 , are based on empirical estimates for the U.S. economy. The social security tax rate, $\tau$, is derived from OECD data on Social Security contributions as a percentage of GDP, and adjusted for labor's share in output (1- $\beta) .{ }^{16}$ The degree of annuitization, $\gamma$, reflects the value of private pension funds as a percentage of U.S. household net weal th. ${ }^{17}$ The aged-dependency ratio, $p$, was set to equal the current ratio of the population aged 65 and over to the population between the ages of 20 and 64 . The value for $\beta$ reflects capital's share of output. Balanced growth in the model requires $\beta+\eta=1 .{ }^{18}$ Using this restriction gives the value for $\eta$ used in the simulations. 
These parameters are the same for all three variations of the model simulated. For the variation in which the means test is binding, the tax rate for social security benefits, $\sigma$, is 0.30 , the tax rate for highincome individuals. The income guarantee parameter, $\zeta$, and the means test parameter, $\xi$, are determined endogenously in the model.

After calculating the baselines, we changed the age mix of the population and re-simulated the economy, keeping a(t) at its baseline path. Specifically, we assumed that each generation through those born at $t=4$ had a 20 percent probability of living throughout the retirement period. Given the absence of population growth in the model, the aged-dependency ratio equals this probability. For the generations born in periods 5,6 , and 7 , the probability of living through the retirement period increased to $0.238,0.37$, and 0.406 , respectively. ${ }^{19}$ These probabilities correspond to the projected aged-dependency ratios for the United States in 2015, 2040, and 2065. ${ }^{20}$

RESULT 1: In all variations of the model, relative to the set of baseline simulations and when the social security tax rate is fixed, an aging population generates growth and lifetime utility paths that dominate the baseline paths.

As stated earlier, if wealth is only partially annuitized, $\gamma<1$, the net effect of increased life span on growth is ambiguous. Result 1 indicates that, given the parameters in Table 2 and the path of aging specified above, the negative effects on saving of reduced bequests and a lower marginal return on saving are dominated by the positive effect on saving of a decline in expected social security benefits. Lifetime utility rises for two reasons. First, the higher growth rate of the economy causes consumption to increase and utility, in turn, to rise. Second, most individuals prefer a long life to a shorter one, so their utility rises with their life span. Thus, a modified MB plan is both feasible and utility-enhancing. For this result, individuals must know that their social security benefits will adjust to

\section{Table 2}

Baseline Parameter Values for the Simulations

\begin{tabular}{c|l}
\hline Parameter & Value \\
\hline$\tau$ & 0.127 \\
\hline$\gamma$ & 0.165 \\
$\beta$ & 0.30 \\
$\eta$ & 0.70 \\
$\rho$ & 0.20 \\
$\sigma$ & 0.30 \\
\hline
\end{tabular}

keep the burden of the program constant.

After incorporating the effects of an aging population into the model, we examined the possibility of phasing out the pay-as-you-go system and replacing it with a fully-funded system that is very much like the PSA plan. That is, we examined whether we can do better than the modified MB plan of Result 1, above. Comparing the results of these simulations with the pure aging effects, the aging baseline (the modified MB plan), allowed us to make comparisons with respect to growth and dynamic social welfare.

RESULT 2: In all variations of the model, raising the annuitization rate, $\gamma$, above some threshold rate in period $t$, and eliminating the social security tax rate, $\tau$, in period $t+1$ results in a lifetime utility path that Pareto dominates the aging economy path (i.e., both workers and retirees would be at least as well off as they are under the present system).

From the perspective of the generation of workers who are currently paying social security taxes, a policy to reduce $\tau$ when they reach retirement will reduce their lifetime utility (even if the policy is announced in advance). This utility reduction can be offset by allowing this generation to increase the annuitization of its wealth, thereby raising the marginal return on its saving. Thus, any Pareto-optimal policy that

\footnotetext{
${ }^{19}$ The time period in which the age structure of the population changes does not affect the results of the model.

${ }^{20}$ These projections are based on estimates by the Board of Trustees of the Federal Old-Age, Disability and Survivors Trust Fund (19)96
} 


\section{Figure 2}

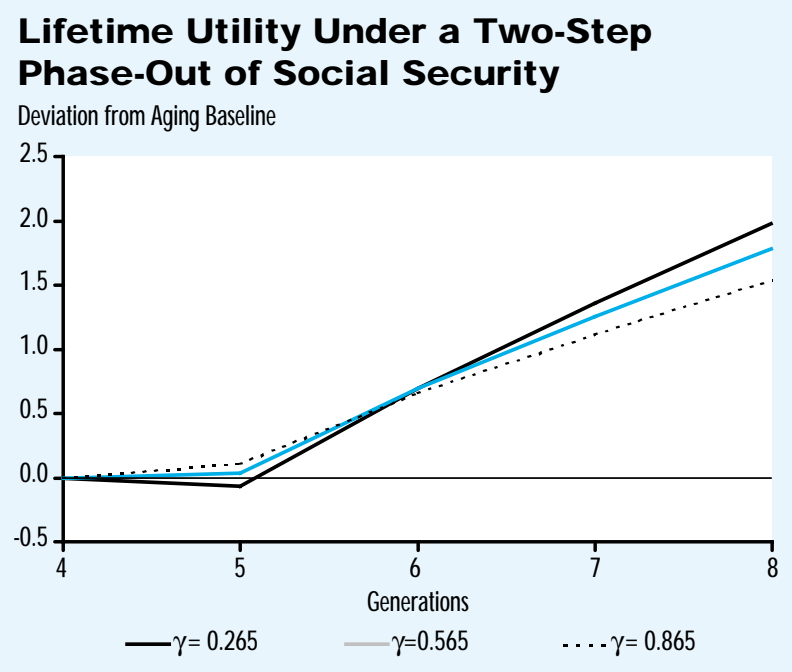

Figure 3

Lifetime Utility Under a Four-Step

Phase-Out of Social Security

Deviation from Aging Baseline

$\tau_{6}=.087, \tau_{1}=.047, \tau_{8}=0$

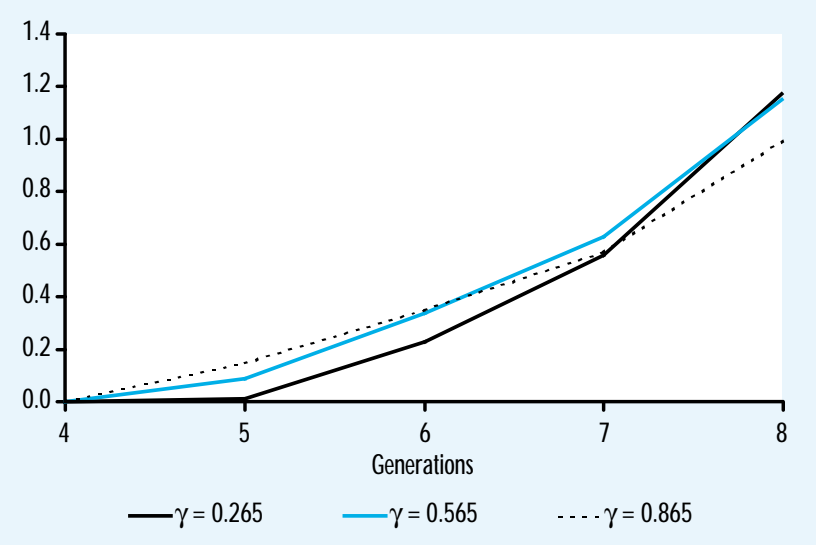

eliminates the pay-as-you-go plan must raise the annuitization rate before it reduces the social security tax rate, and this can be done only by means of actuarially fair contracts. If the maximum annuitization rate is set too low, current workers will be worse off with the phase-out plan. Beyond this, the level to which $\gamma$ is raised depends on the weight given by policymakers to the preferences of current workers versus future generations. Current workers would prefer a high annuitization rate, while future generations would benefit from lower annu- itization rates. Figure 2 illustrates these results for the case in which neither the means test nor the income guarantee is binding. The annuitization rate, $\gamma$, is increased in period 5 , and the tax rate, $\tau$, is lowered in period 6 . The choice of these periods does not affect the results. The results for the case in which the means test is binding and the one in which the minimum guarantee is binding are similar to those shown in Figure 2 . In the case of a binding minimum guarantee, utility is higher without the income guarantee than with it, so completely phasing out the pay-as-you-go system is both feasible and welfare-enhancing.

RESULT 3: In all variations of the model, raising the annuitization rate, $\gamma$, above some threshold rate in period $t$, and reducing the social security tax rate, $\tau$, in periods $t+1$, $t+2$, and $t+3$ also results in a lifetime utility path that Pareto dominates the aging path.

As Figure 3 shows, extending the phase-out period of the pay-as-you-go system does not change the basic result that moving to a fully-funded system can be Pareto optimal, nor does it change the preferences of current generations versus future generations with regard to the annuitization rate. However, gradually reducing the social security tax rate reduces the minimum $\gamma$ needed to ensure that the phase-out plan is Pareto optimal.

Figure 4 compares the results of the two-step phase-out plan described in Result 2 with the four-step phase-out plan described in Result 3. The top panel indicates, as noted above, that with a gradual reduction in the social security tax rate, the annuitization rate does not have to be raised as high to make the current generation of workers better off. All three panels indicate the intergenerational effects of a short phase-out period versus a long one. Workers who are currently paying social security taxes would prefer a longer phaseout period, since this reduces their portion of the burden. Because the present social security system has a negative effect on 
saving, the more rapid the phase-out, the more rapid the rise in saving and thus economic growth. Because this higher growth rate would raise the lifetime utility of future generations through its effect on consumption, future generations would benefit from a short phase-out period.

Independent of the phase-out period, and for a plan very like the PSA plan, actuarial balance can be maintained without imposing extraordinary taxes. Our results differ from those of the Office of the Chief Actuary because ours encompass the general equilibrium effects of aging, annuitization, and tax relief on saving.

\section{CONCLUSION}

This analysis establishes that, in the model economy, a pay-as-you-go social security scheme can be replaced by an actuarially fair pension system very like the PSA plan suggested by the Advisory Council on Social Security. This result holds even in the presence of a minimum income guarantee means tests for benefits. Two factors drive this result. First, in our model, opening up actuarially fair annuity markets raises the return on savings, thereby encouraging higher saving rates. Second, the pay-as-you-go system reduces saving in the economy because benefits are not tied directly to contributions.

Eliminating such a system would raise the saving rate. These two positive effects on saving would increase the growth rate of the economy, providing benefits for all individuals. While our results indicate that the move to a fully funded system would have clear benefits for future generations, it cautions that the benefits for current workers are smaller and less easy to obtain.

\section{REFERENCES}

Auerbach, Alan J., Laurence J. Kotlikoff, and David N. Weil. "The Increasing Annuitization of the Elderly- Estimates and Implications for Intergenerational Transfers, Inequality, and National Saving," NBER Working Paper №. 4182, 1992.

Board of Trustees of the Federal Old-Age, Disability and Sunvivors Trust Fund. Annual Report, 1996.

\section{Figure 4}

\section{Lifetime Utility Under Alternative} Phase-Out Plans

Deviation from Aging Baseline
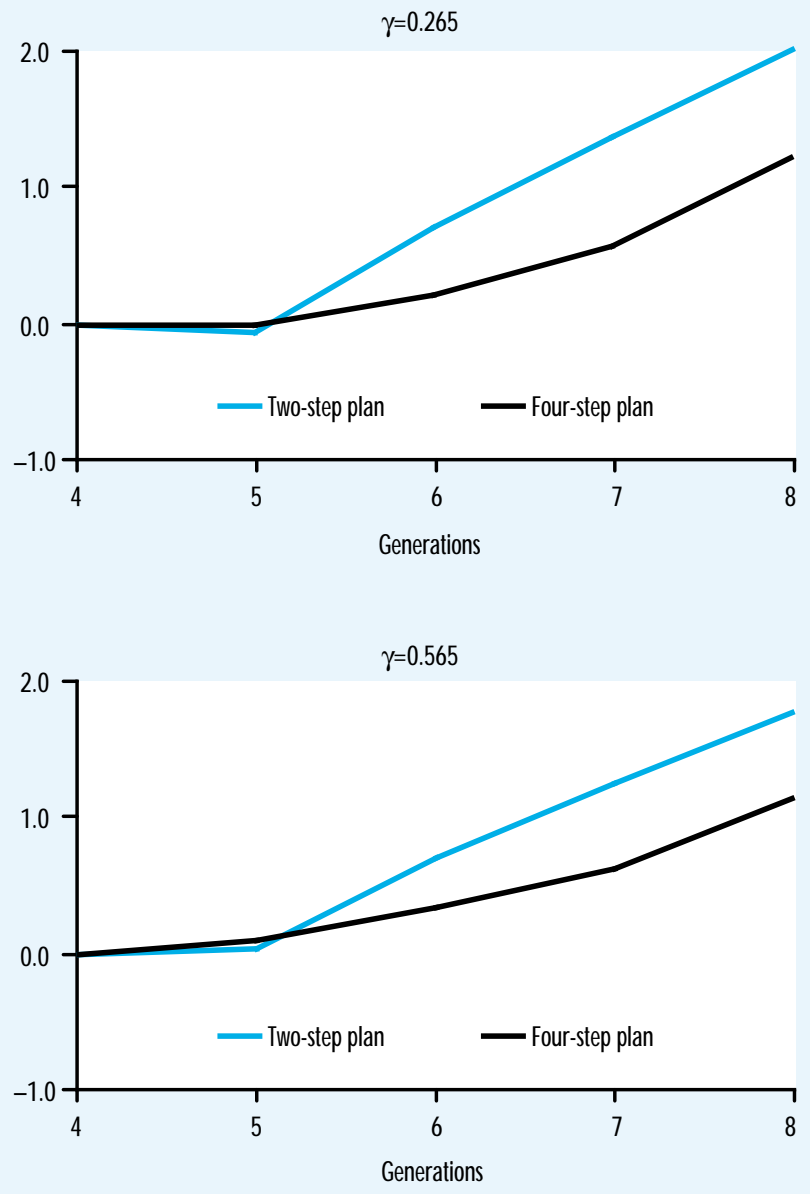

$\gamma=0.865$

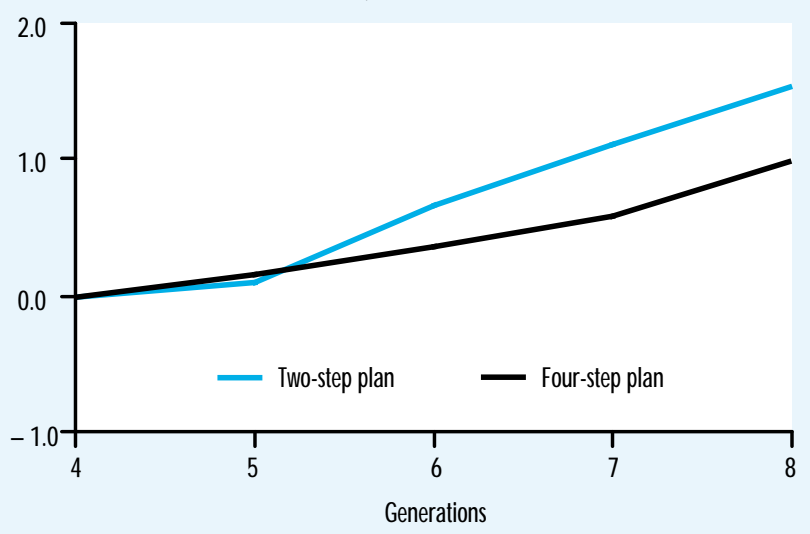


Eckstein, Zvi, Martin Eichenbaum, and Dan Peled. "Uncertain Lifetimes and the Welfare Enhancing Properties of Annuity Markets and Social Security," Journal of Public Economics (April 1985) pp. 303-26.

OECD. Revenue Statistic of OECD Member Countries: 1965-1992. Paris: OECD, 1993.

Pecchenino, Rowena, and Patricia Pollard. "The Effects of Annuities, Bequests, and Aging in an Overlapping Generations Model of Endogenous Growth," Economic Joumal (January 1997), pp. 26-46.

and _. _. . "The Transition from a Pay-As-You-Go to a Fullyfunded Social Secunity System: Is There a Role for Social Insurance," Federal Reserve Bank of St. Louis Working Paper No. 97. 022A, November 1997.

Romer, Paul. "Increasing Returns and Long-Run Growth," Journal of Political Economy (October 1986), pp. 1002-37.

Sheshinski, E., and Y. Weiss. "Uncertainty and Optimal Social Security Systems," Quarterly Joumal of Economics (May 1981), pp. 189 . 206.

Social Secunity Administration. Social Security Programs in the United States, Social Security Administration, 1997.

Social Security Advisory Council. Report of the 1994-1996 Advisory Council on Social Security, Vols. I and II, Social Security Administration, 1997.

U.S. Congress, House of Representatives, Committee on Ways and Means. Greenbook: Background Matenial and Data on Major Programs Within the Jurisdiction of the Committee on Ways and Means, U.S. Government Printing Office, 1996. 